\title{
SOTERIOLOGICAL TRAJECTORIES, EVOLVING MEANING AND CONSTRUCTIVE THEOLOGY
}

\author{
David N Field \\ Research Fellow, Department of Theology and Religion \\ University of Zululand
}

\begin{abstract}
This article is an appreciative but critical appraisal of certain themes from Klaus Nürnberger's Theology of the Biblical Witness with a focus on its significance for constructive theology. It analyses his understanding of soteriological trajectories and underlying streams of meaning and then raises critical questions with regard to his use of evolutionary theory, the nature of the streams of meaning, the problems of historical construction and the reduction of the biblical witness to soteriology.
\end{abstract}

Key words: Biblical Theology, K Nürnberger, Soteriology, Systematic Theology

Klaus Nürnberger has made a significant contribution to the discussion on the relationship between constructive theology and the Bible. Nürnberger's approach is significant for a number of reasons. First, while affirming that the Bible is a "means of grace", he is totally honest in facing its problematic character in terms of its diversity, contradictions and morally offensive features. Second, he affirms the distance between the Bible and constructive theologising recognising that the Bible does not address many contemporary issues and insisting that our concerns are not to be read back into it. Third, he takes seriously the complex manner in which the biblical writings came into being emphasising the significance of the internal dialogue, debate and contradictions amongst the biblical traditions. Fourth, he affirms their contextual character and entanglement in the power struggles of history. Fifth, he sees the manner in which the biblical authors reinterpreted the tradition as a model for constructive theology. Sixth, he provides a model for doing theology that both relates to the Bible yet goes beyond it. ${ }^{2}$

For Nürnberger the core of the biblical traditions is their witness to God's salvific response to specific situations of human need. The biblical authors describe a wide variety of needs in which there is no permanent hierarchy, different contexts give rise to different needs. Spiritual or transcendent needs are highly significant, but they do not exist on their own, rather they are the depth dimensions of immanent needs. Further, when God acts in response to situations of need God always uses human agents. Yet, believers recognise God's action and interpret it in terms of the traditions they have received. In arguing for a soteriological core to the biblical witness, Nürnberger rejects all ontological or metaphysical theorising.

The experiences of God's salvific response were remembered and narrated in "prototypical narratives" (2003:14). These narratives are retold and ritually enacted. When

A review essay on Klaus Nürnberger's Theology of the Biblical witness: An evolutionary approach
(Hamburg: LIT Verlag, 2002).
Nürnberger is not the only theologian who has made such a proposal; it is unfortunate that he has not interacted with the somewhat similar proposal made by Paul D Hanson (1978, 1982, 1986). 
the people encounter new situations of need, they are reinterpreted to address these situations. New experiences of redemption are also narrated, giving rise to other prototypical narratives that are in turn reinterpreted in new contexts. The new situations of need prompt new understandings of God's intention for human well being, broadening and deepening the vision inspired by the prototypical narratives. However, this process of reinterpretation always takes place within the complexities of human social relations. Thus its witness to God's activity is always partial, at times obscuring or contradicting the divine intention. The result of the process is the development of streams of tradition that Nürnberger describes as soteriological trajectories. Over time these trajectories display "considerable adaptations, mutations, jumps, and in the end, the inversion of their original meaning." (2002:14). These trajectories interact with each other eventually merging into "a larger story - the sacred story of Yahweh's covenant with Israel". (Nürnberger 2000:303) The examination of the development and merger of the different trajectories uncovers incompatible affirmations that contradict and critique each other as well as those that complement and enrich each other. Out of this process, particularly as it culminates in Christ, emerges a picture of God's intention for "the comprehensive wellbeing of all his creatures" (Nürnberger 2000:284).

Two ideas play a significant role in Nürnberger's proposal: The first is evolutionary theory and second the concept of underlying streams of meaning.

In order to explain the emergence and development of these trajectories Nürnberger draws on evolutionary theory. His model of evolution is primarily derived from physics, as he explains it:

...reality is constituted by the flow of energy in time and space caused by differences in power concentrations. As they flow through time and branch out through space, currents of energy interact with each other and form evermore complex systems of relationships (2002:70).

To this he adds the concepts of "entropy" - concentrations of power exist by causing deterioration in other places; "acceleration" - the flow of energy tends to increase in speed; "chaos" - the turmoil that results from excessive acceleration; and "emergence" - the development of higher levels of complexity out of chaos. Evolutionary theory is not a mere metaphor or heuristic device, for mindsets, ideas, norms and visions are part of evolving reality and thus "consist of emerging and evolving networks of interaction determined by time, space and energy differentials" (2002:71).

Nürnberger argues that the biblical narratives, motifs and ideas are expressions of underlying streams of meaning. The significance of the biblical material is the insight it gives to the evolution of the stream of meaning, that is, the developing understanding of God's redemptive purposes and goals. These streams mutate and develop in new directions in response to new situations of need or as consequence of an encounter with other streams of meaning. This is a historical evolutionary process, and thus the streams of meaning have a uni-directional flow toward a fuller understanding of God's intention. This flow of meaning is not to be identified with the historical progression of ideas in the biblical texts, but with the progression of redemptive insight underlying the text. The biblical texts are particular historical expressions of the underlying stream of meaning. The historical development of biblical ideas, motifs and exemplars is a complex process of progression, stagnation, retrogression and even collapse. Hence, neither individual texts nor the historical development of the biblical texts is to be understood as a normative witness to God's redemptive intention. What is normative is the direction of the stream of meaning underlying the texts. 
The theological task is to discern the stream of meaning underlying the texts by making use of the best critical tools available to us. As the meaning of the texts is contextually specific this entails historical reconstruction in order to discern what was being said to particular people at a particular time. While Nürnberger acknowledges the problematic character of such reconstructions and the confused situation in contemporary biblical scholarship, he still argues for its necessity asserting that a reconstruction of a probable scenario is all that is required for his project.

It must be further noted that the evolution of the streams of meaning did not mature within the biblical documents. "When the New Testament documents were written, slavery had not been rejected, democratic principles had not developed and ecological concerns had not emerged." (Nürnberger 2002:60). As we encounter new situations of need, so we come to a fuller understanding of the streams of meaning to which the biblical trajectories bear witness. Hence, the task of systematic theology is not to repeat what is found in the biblical texts, but to extrapolate the thrust of the interacting steams of meaning beyond the Bible to address the new situations of need. In doing so we come to a fuller and deeper understanding of what God is doing to bring comprehensive wellbeing to all God's creatures.

The norm by which we are to interpret and evaluate both our contemporary theologising and the biblical material is the evolving understanding of "God's vision of comprehensive wellbeing which translates into God's concern for specific deficiencies in wellbeing" (Nürnberger 2002:109).

In responding to Nürnberger, I wish to note some areas of critique. The first is his use of evolutionary theory and the related issues of the underlying streams of meaning and the importance and problems of historical construction. The second is the soteriological reduction of the biblical witness. In doing so, I wish to emphasise the significance of Nürnberger's proposal and that my critique arises out of an appreciation for the proposal and a desire to build on it.

First, Nürnberger's use of evolutionary theory gives rise to significant questions as to the extent to which a scientific model developed in the natural sciences can be applied to the development of religious insights underlying a body of literature. His use of the physics of evolution to interpret the evolution of the streams of meaning as a uni-directional linear progression of insight obscures and over-systematises the complex diversity of the biblical material. For example, Nürnberger has argued that the second and earlier of the Genesis creation story displays a patriarchal understanding of the relationship between male and female, while the first and later one a more egalitarian one with both male and female given royal authority over the earth. Hence, the flow of the trajectory from patriarchy to egalitarianism is normative (see Nürnberger 1997). Yet in relation to humanity's relation to otherkind one could argue that the reverse is true, the second story portrays a relationship of harmony and care while the first portrays one, as Nürnberger recognises, of dominion and conquest. Biological evolution perhaps provides a better model with its portrayal of a vastly complex scenario. Here the evolutionary process is much more like a tree with many branches emerging as diverse organism adapt and change in relation to each other and their context. These developments and changes cannot be reduced to linear progress. Instead, we have a process in which certain genetic potential is developed and evolves while other genetic potential simplifies, degenerates or disappears. I would suggest that a similar process can be observed in the biblical material. In this model, the two accounts of creation would not be related in terms of linear progress, but rather as different branches that develop different insights in relation to their specific contexts. Each has a specific contribution to make and by relating them together, we can come to a more comprehensive 
vision of creation and God's purpose for it. Here, too, careful and critical theological judgement has to be exercised in determining what contributes to such a vision and what does not. Why do we select the egalitarian tendency of the first creation narrative and the emphasis on care for the earth from the second?

The problematic character of Nürnberger's use of evolution is intensified by the tendency towards a realistic interpretation of scientific theories as the products of inductive research. Thus, for Nürnberger, evolutionary theory is a description of the reality of which the biblical traditions form a part and not merely a heuristic device. Yet, as Nürnberger acknowledges, the biblical material does not display an evolutionary progress of redemptive insight. Thus, while Nürnberger, describes evolutionary theory as enabling us to read the Bible "the way it was written" (2002:70) and that the biblical traditions are shaped by the process of evolution as described by physics, this applies to the underlying streams of meaning. The relationship between the evolution of redemptive insight and the complex history of the biblical material is ambiguous. Nürnberger argues for the importance of historical investigation and reconstruction as the historical changes reveal the direction of the flow of meaning, thus implying that the later supersedes the earlier. However, he also argues that later developments might be retrogressive and that the insights of the original authors in their situations of need have priority over that of later redactors. We might further ask: How does evolutionary theory account for the inversion of meaning that Nürnberger proposes?

What is the ontological status of the streams of meaning? Is Nürnberger postulating that they exist in some sense independent of the theologians theorising, maybe analogous to the way physicists postulate the existence of sub-atomic particles? Then the task of theology is to discover them through inductive research. This appears to be the consequence of his argument that ideas are part of the evolving reality. Or are these streams of meaning merely theological constructions and thus human attempts to make sense of the complex data contained in the Bible?

Nürnberger's proposal is dependent on historical reconstruction. He argues that:

Truth is not a timelessly valid body of propositions, but a system of sign posts which guide us through our earthly lives. A signpost may be reliable at a given juncture of the road, but misleading if transplanted to another juncture (2002:107).

As a consequence of the contextual character of truth, the interpretation of the meaning and significance of a particular biblical passage or tradition is shaped by our reconstruction of its socio-historical context. Different reconstructions will lead to very different interpretations of the passages concerned and hence, in Nürnberger's theory, of the trajectory and underlying stream of meaning. Yet, as Nürnberger acknowledges, the present state of historical criticism is such that we can have very little assurance as to the validity of any reconstruction of the context of many biblical texts. Further, this situation is unlikely to change unless there are some major archaeological discoveries in the future. Thus, while I wish to affirm the need for historical reconstruction, it must be done with a clear recognition of its limitations and of the possibility of other reconstructions which could lead to very different interpretations of a particular text. In most cases we do not have any other access to the event that is interpreted as God's act of redemption. All we have are the biblical narratives as they have been retold and reinterpreted.

Most fundamentally, Nürnberger's need-response model is reductionist despite his understanding of God's vision being that of the comprehensive wellbeing for all God's creatures. Biblical materials that address issues of theological cosmology and ontolology, 
such as the creation narratives, are interpreted as having soteriological significance. This soteriological focus leads to a failure to address God's diverse non-soteriological relationships with all creation. The result is a theology that remains anthropocentric and thus unable to adequately address the issues, such as the ecological crisis, which Nürnberger wishes to address.

Even in terms of God's relation to humanity, it is reductionist in three ways. First, it is reductionist in its analysis of transcendent needs as depth dimensions of immanent needs, particularly when the transcendent needs are interpreted in the categories of the need for meaning, acceptance and authority. Concepts such as forgiveness, fellowship with God, and sanctification, while in some cases related to immanent needs, are not merely their depth dimension, nor can they be adequately interpreted in terms of the categories of meaning acceptance and authority. A definition of comprehensive wellbeing that arises from the biblical traditions must be communal and have at its centre fellowship with and worship of God (see Field 1998, 1999, 2002). Second, related to this, the focus on human need seems to run contrary to the theocentric focus of much of the biblical material. In Nürnberger's theory, it is difficult to account for the prevalence of the theme of true and false worship (idolatry). Third, it ignores the importance of the negative experiences in shaping Israel's understanding of God and God's purposes, experiences that were interpreted as God's absence, God's failure to act or God's acts of judgement. The most prominent of these was the experience of exile, an experience that is generally agreed to have had a profound affect on the shaping of the Old Testament traditions. Acts of salvation can only be adequately interpreted when they are understood in relation to these negative experiences.

Despite the above we remain in Nürnberger's debt, not the least for his clear articulation of his proposal and its consequences. I hope that he will move beyond this hermeneutical proposal and develop a systematic theology on this basis.

\section{BIBLIOGRAPHY}

Field, David N 1998. "The Ethics of Sustainable Development”, in Louise Kretzschmar and Len Hulley (eds.), Questions about Life and Morality - Christian Ethics in South Africa Today, Pretoria: Van Schaik, 219-229.

---- 1999. "Snakes in an African Eden: Towards a Theological Ethic for Ecotourism and Conservation". Scriptura 69, 165-180.

---- 2002. "Stewards of Shalom: Toward a Trinitarian Ecological Ethic." Quarterly Review 22:4, 383-396.

Hanson, Paul D 1978. Dynamic Transcendence: The Correlation of Confessional Heritage and Contemporary Experience in a Biblical Model of Divine Activity. Philadelphia: Fortress.

---- 1982. The Diversity of Scripture: A Theological Interpretation. Philadelphia: Fortress Press.

--- 1986. The People Called: The Growth of Community in the Bible. San Francisco: Harper and Row.

Nürnberger, Klaus 1997. "The Conquest of Chaos: The Biblical Paradigm of Creation and its Contemporary Relevance". Journal of Theology for Southern Africa 98, 45-63.

---- 2000. "Biblical Authority between Fundamentalism and Postmodernism; Elements of an Evolutionary Hermeneutic". Religion and Theology 7/3, 284-324. 
---- 2002. Theology of the Biblical Witness: An Evolutionary Approach. Münster: LIT Verlag. 